\title{
STUDI TINGKAT PENGETAHUAN IBU TENTANG KONSUMSI AIR BERSIH DAN SEHAT DI DUSUN
} KESAMBEN RW 04 PORONG SIDOARJO

\author{
Meli Diana ${ }^{1}$ \\ 'Akademi Keperawatan Kerta Cendekia Sidoarjo
}

Corresponding: sonoera684@gmail.com

\begin{abstract}
Abstrak
Introduction. Air bersih yang sehat adalah salah satu jenis sumber daya berbasis air yang bermutu baik dan biasa dimanfaatkan oleh manusia untuk dikonsumsi atau dalam melakukan aktivitas mereka sehari-hari termasuk diantaranya adalah sanitasi. Penelitian ini bertujuan untuk mengetahui tingkat pengetahuan ibu tentang konsumsi air bersih dan sehat di Dusun Kesamben Rw 04 Porong Sidoarjo. Methods. Metode penelitian yang digunakan dalam penelitian ini adalah penelitian deskriptif. Populasi dalam penelitian ini adalah semua ibu di Dusun Kesamben Rw 04 Porong Sidoarjo yang berjumlah $260 \mathrm{ibu}$ dan jumlah sampel yang digunakan berjumlah 157 responden. Teknik Sampling yang di gunakan adalah rendom sampling. Teknik pengumpulan data dilakukan dengan kuisioner dengan jumlah soal 10 soal. Data yang terkumpul disajikan dalam bentuk tabulasi silang dan narasi, selanjutnya diinterpretasikan menjadi suatu kesimpulan. Results. Hasil Penelitihan ini menunjukkan bahwa Kurang dari setengah responden memiliki pengetahuan kurang sebesar 49\% Dengan Tingkat Pengetahuan ibu tentang konsumsi air bersih dan sehat di Dusun Kesamben RW 04 Porong Sidoarjo. Discussion. Untuk itu diharapkan bagi perawat semakin meningkatkan pula pelayanan berupa pendidikan kesehatan pada masyarakat agar semakin banyak orang meningkat pengetahuannya mengenai kesehatan terutama mengkonsumsi air bersih yang sehat untuk menekan terjadinya penyakit yang di sebabkan karena air yang tidak bersih.
\end{abstract}

Keywords: Tingkat Pengetahuan, ibu, air bersih yang sehat

\section{Pendahuluan}

Air bersih adalah salah satu jenis sumber daya berbasis air yang bermutu baik dan biasa dimanfaatkan oleh manusia untuk dikonsumsi atau dalam melakukan aktivitas mereka sehari-hari termasuk diantaranya adalah sanitasi. syarat-syarat air minum adalah tidak berasa, tidak berbau, tidak berwarna, dan tidak mengandung logam berat Walaupun air dari sumber alam dapat diminum oleh manusia, terdapat risiko bahwa air ini telah tercemar oleh bakteri (misalnya Escherichia coli) atau zat-zat berbahaya. Walaupun bakteri dapat dibunuh dengan memasak air hingga 100 ${ }^{\circ} \mathrm{C}$, banyak zat berbahaya, terutama logam, tidak dapat dihilangkan dengan cara ini. merupakan salah satu kebutuhan pokok manusia yang dibutuhkan secara berkelanjutan dan Penggunaan air bersih sangat penting untuk konsumsi rumah tangga, kebutuhan industri dan tempat umum. Karena pentingnya kebutuhan akan air bersih, maka hal yang wajar jika sektor air bersih mendapatkan prioritas penanganan utama karena menyangkut kehidupan orang banyak. Penanganan akan pemenuhan kebutuhan air bersih dapat dilakukan dengan berbagai cara, disesuaikan dengan sarana dan prasarana yang ada. Di daerah perkotaan, sistem penyediaan air bersih dilakukan dengan sistem perpipaan dan non perpipaan. Sistem perpipaan dikelola oleh Perusahaan Daerah Air Minum (PDAM) dan sistem non perpipaan dikelola oleh masyarakat baik secara individu maupun kelompok, (Tjahjono, 2007). Kebutuhan air bersih merupakan kebutuhan yang tidak terbatas dan berkelanjutan. Sedang kebutuhan akan penyediaan dan pelayanan air bersih dari waktu ke waktu semakin meningkat yang terkadang tidak diimbangi oleh kemampuan pelayanan. Peningkatan kebutuhan ini disebabkan oleh peningkatan jumlah penduduk, peningkatan derajat kehidupan warga serta perkembangan kota/kawasan pelayanan ataupun hal-hal yang berhubungan dengan peningkatan kondisi sosial ekonomi warga (Notodarmojo, 2006). Kecamatan porong adalah wilayah yang dekat dengan lumpur lapindo sehingga menyebabkan air di wilayah Kesamben wunut Porong menjadi kuning dan berbau sehingga tidak layak untuk dikonsumsi, tetapi warga setempat tetap menggunakan air tersebut untuk memasak, dikonsumsi sebagai air minum, mencuci dan mandi. Akibatnya sebagian warga menderita penyakit gatal-gatal dan diare. Pengadaan air bersih di Indonesia khususnya untuk skala yang besar masih terpusat di daerah perkotaan, dan dikelola oleh Perusahan Air Minum (PAM) kota yang bersangkutan. Namun demikian secara nasional jumlahnya masih belum mencukupi dan dapat dikatakan relatif kecil yakni 16,08 $\%$ (Ghernaoutetal, 2009). Untuk daerah yang belum mendapatkan pelayanan air bersih dari PAM umumnya mereka menggunakan air tanah (sumur), air sungai, air hujan, air sumber (mata air) dan lainnya. Minimnya penggunaan air bersih dan sehat di desa wunut di karenakan kurangnya pengetahuan ibu tentang penggunaan air bersih dan sehat. Pengetahuan itu sendiri dipengaruhi oleh beberapa faktor diantaranya 
pendidikan yang rendah dan informasi yang kurang. Akibat dari jangka pendek jika mengkonsumsi air yang tidak bersih dan sehat akan menimbulkan penyakit perut seperti diare,dan menyebabkan penyakit kulit seperti kudis dan gatal-gatal.sedangkan jika mengkonsumsi air yang tidak bersih dan sehat dan terlalu banyak logam dalam jangka yg panjang akan menyebabkan penyakit yang berbahaya seperti kanker dan penyakit-penyakit bahaya lainnya yang menyerang organ-organ lain. Konsep solusi yang ditawarkan peneliti untuk mengatasi masalah tersebut adalah bekerjasama dengan puskesmas dan pemerintahan desa setempat untuk memberikan penyuluhan kepada para ibu tentang penggunaan air bersih agar warga setempat menggunakan Air PDAM ataupun air sumur yang bersih dengan ciri-ciri yaitu jernih, tidak berwarna, tidak berbau, tidak mengandung bakteri, dan tidak mengandung campuran yang merusak organ tubuh seperti zat besi. sehingga ibu mengkonsumsi air yang bersih dan sehat dalam kebutuhan sehari-hari. dan di harapkan semua ibu menggerti tentang penggunaan air bersih sehingga tidak memakai air yang tidak berkualitas.

\section{Metode dan Bahan}

Dalam penelitian ini desain yang di gunakan adalah deskriptif, merupakan suatu metode penelitihan yang digunakan dengan tujuan untuk membuat gambaran tentang suatu keadaan secara obyektif (Notoatmojo, 2003). Peneliti ingin mengetahui bagaimana tingkat pengetahuan ibu tentang mengkonsumsi air bersih dan sehat. Penelitian ini dilaksanakan pada tanggal 21-22 November 2016 di dusun kesamben RW 04, Porong, Sidoarjo. Populasi dalam penelitian ini adalah semua Ibu yang tinggal di dusun kesamben rw 04 porong sidoarjo yang berjumlah 260 responden. Dengan menggunakan teknik sampling Simple Random Sampling, maka sampel yang digunakan sebanyak 157 responden. Pada penelitian ini instrumen yang digunakan adalah kuesioner yang terdiri dari soal tertutup (close ended question) tipe pilihan ganda yang berjumlah 10 soal. Pada penelitian ini peneliti menganalisis dengan menggunakan analisis deskriptif kualitatif yaitu suatu analisis yang menggunakan predikat kepada variabel yang diteliti sesuai dengan kondisi sebenarnya. Pada variabel pengetahuan diukur dengan ketentuan soal benar dinilai 1 dan soal salah dinilai 0 .

\section{Hasil Penelitian}

Dari hasil pengumpulan data diketahui bahwa responden yang berpengetahuan baik sebanyak 30 responden (19\%), berpengetahuan cukup sebanyak 50 responden $(32 \%)$, dan yang berpengetahuan kurang sebanyak 77 responden (49\%). Data hasil penelitian dapat dilihat pada Tabel 1.1.
Tabel 1.1 Tabel Data Khusus Menyajikan Tingkat Pengetahuan ibu tentang konsumsi air bersih dan sehat Di Dusun kesamben Rw 04 porong Sidoarjo

\begin{tabular}{|l|l|c|c|}
\hline No. & Pengetahuan & Frekuensi (F) & Persentase $(\%)$ \\
\hline 1. & Baik & 30 & 19 \\
\hline 2. & Cukup & 50 & 32 \\
\hline 3. & Kurang & 77 & 49 \\
\hline \multicolumn{2}{|l|}{ Total } & 157 & 100 \\
\hline
\end{tabular}

\section{Pembahasan}

Berdasarkan hasil penelitian di Dusun Kesamben RW 04 Porong Sidoarjo, dapat diketahui bahwa rata-rata responden memiliki tingkat pengetahuan kurang tentang konsumsi air bersih dan sehat. Hal ini terbukti dari data hasil penelitian pada tabel 1.1 diperoleh yaitu sebanyak 30 responden (19\%) responden memiliki tingkat pengetahuan baik, 50 responden (32\%) memiliki tingkat pengetahuan cukup, dan 77 responden (49\%) memiliki pengetahuan kurang. Pengetahuan dipengaruhi oleh dua faktor, yaitu faktor eksternal yang terdiri dari: umur, intelegensi dan faktor eksternal yang terdiri dari: pengalaman pribadi, pendidikan, pekerjaan, informasi dan lingkungan (Notoatmojo, 2003).

Banyaknya responden berumur 21-30 tahun yang tingkat pengetahuannya baik dikarenakan lebih banyak menerima informasi dan proses perkembangan mental lebih baik dari yang berumur lebih tua sehingga umur yang lebih muda lebih cepat menerima informasi karena masih mempunyai daya ingat yang kuat. Sedangkan yang berumur lebih tua pengalaman pribadipun dapat digunakan sebagai upaya memperoleh pengetahuan dengan cara mengulang kembali pengalaman yang pernah diperoleh dalam memecahkan permasalahan yang dihadapi pada masa lalu (Arikunto, 2006). Semakin tua umur seseorang maka proses perkembangan mentalnya bertambah baik akan tetapi pada umur- umur tertentu, bertambahnya proses berkembangnya mental ini tidak secepat seperti ketika berumur belasan tahun (Notoatmojo, 2003).

Dengan latar belakang pendidikan yang semakin tinggi yang dimiliki seseorang kemungkinan informasi yang didapatkan juga semakin banyak sehingga pengetahuan juga bertambah. Menurut Nursalam(2003), Hal ini membuktikan bahwa pendidikan mempengaruhi tingkat pengetahuan seseorang, karena dengan semakin tingginya pendidikan seseorang maka semakin mudah seseorang tersebut untuk menerima informasi, sehingga semakin banyak pula pengetahuan yang dimiliki.

Dengan pekerjaan lah orang dapat memperoleh informasi di lingkungan kerjanya seperti halnya pegawai negeri yang selalu bisa meluangkan waktunya 
untuk mencari informasi melalui media elktronik maupun media cetak sedangkan yang bekerja sebagai pegawai swasta tidak mempunyai waktu untuk memperoleh informasi karena kesibukan di lingkungan kerjanya.Dengan bekerja seseorang dapat berinteraksi dengan orang lain pada lapisan masyarakat luas, sehingga mampu mendapatkan informasi dari berbagai sumber untuk menambah pengetahuan (Iqbal, 2007).

Semakin banyak penghasilan seseorang akan mudah menerima informasi karena dengan pengasilan yang cukup seseorang bisa mampu membeli media elektronik maupun media cetak untuk mendapatkan informasi dan jika seseorang yang berpenghasilan kurang sangat mempengaruhi dalam memperoleh informasi,karena untuk mendapatkan informasi juga memerlukan biaya yang cukup. Menurut Cherin (2009) penghasilan memiliki kaitan dengan keinginan seseorang yang akan menambah pengetahuan.

Banyaknya informasi yang didapat seseorang dari berbagai sumber menjadikan orang tersebut berpengetahuan baik, ditambah lagi bila informasi benar-benar diserap dan diterapkan di keseharian.Informasi akan memberikan pengaruh pada pengetahuan seseorang, meskipun seseorang mempunyai pendidikan yang rendah tetapi jika ia mendapatkan informasi yang baik dari berbagai media misalnya televisi, radio dan surat kabar hal ini akan dapat meningkatkan pengetahuan seseorang (Notoatoatmodjo, 2003).

Seiring perkembangan teknologi penyuluhan saat ini sudah diabaikan oleh seseorang karena kebanyakan dari seseorang malas untuk mengikuti penyuluhan yg di karenakan menyita waktu mereka sehingga mereka memilih media elektronik untuk di jadikan sumber informasi yaitu melalui radio dan televisi tapi juga melalui internet dengan kecanggihan sistem komputer (Badudu, 2001).

\section{Simpulan}

Pada bab ini akan disajikan kesimpulan dari hasil penelitian Studi Tingkat Pengetahuan ibu tentang konsumsi air bersih dan sehat di Dusun Kesamben RW 04 Porong Sidoarjo, dapat disimpulkan bahwa rata-rata responden memiliki pengetahuan kurang tentang konsumsi air bersih dan sehat yaitu sebanyak 77 responden (49\%) di Dusun kesamben RW 04 Porong Sidoarjo.

\section{Saran}

Hasil penelitian ini dapat dijadikan bahan referensi untuk penelitian yang selanjutnya diharapkan dapat dilakukan dengan mengambil karakteristik yang berbeda dari penelitian ini dan menambahkan variabel dalam penelitian selanjutnya. Serta melakukan uji validitas dan reabilitas terlebih dahulu untuk instrumen penelitian sehingga hasil penelitian lebih valid. Diharapkan kepada para responden yang telah banyak mengetahui tentang diabetes untuk juga menerapkan dalam kehidupan sehari-hari, menerapkan pola hidup sehat demi mencegah terjadinya diabetes karena ilmu yang bermanfaat adalah ilmu yang diterapkan di kehidupan kita. Diharapkan untuk lebih sering terjun ke tengah-tengah masyarakat sebagai bentuk peningkatkan pendidikan kesehatan yang lebih baik dan berkelanjutan demi terwujudnya peningkatan kesehatan masyarakat melalui pelayanan kesehatan secara langsung di lingkungan/komunitas.

\section{Daftar Pustaka}

Alimul H,A.Aziz. 2003. Riset Keperawatan dan Teknik Penulisan Ilmiah.Jakarta:Salemba Medika.

Anonimus,2006.bakteri yang ada di dalam air yang tidak bersih. Jakarta: Media Ausculapius

Arikunto, Suharsimi 2006. Metode Penelitian Praktis.Jakarta:PT. Rineka Cipta.

D.Ghernaoutetal,2009. Manfaatair bersih yang sehat.jakarta PT Rineka cipta.

Kusnaedi, 1995. Mengolah air bersih dan air kotor untuk air minum Jakarta : salemba

Kusnaedi, 2004. Syarat-syarat air minum yang berkualitas.Jakarta: salemba medika.

Koran Jakarta, Minggu 18 Oktober 2012.

Kurniawan. 2010.Ciri-ciri air minum bersih dan sehat.jakarta: EGJ.

Manahan, Stanley E. 1995. Environmental Chemistry.Sixth Edition. Columbia. Lewis Publishers.

Maulana, Arman. 2010. Bahaya konsumsi air yang tidak bersih. tsubas.wordpress.com. Diakses pada 10 Desember 2011 pada pukul 18.09 WIB..

Nisa', Khoirun. 2005. Diakses pada 06 Maret 2013 pada pukul 02.38 WIB.

Nursalam dan Pariani, S. (2003). Pendekatan Praktis Metodologi Riset Keperawatan. Jakarta: Sagung Seto.

Nursalam. 2003. Konsep dan Penerapan Metodologi Penelitian Klinik. Jakarta: Bina Aksara Rupa.

Notoatmodjo, Sukidjo, Prof. Dr. 2003. Metodologi Penelitian Kesehatan Cetakan III. Jakarta: Rineka Cipta.

Pertiwi, Indah. 2008. Ciri-ciri air bersih yang layak minum.info-kesehatan.net. Diakses pada 06 Maret 2013 pada pukul 00.22 WIB.

Syafran,2005. pengadaan air bersih yang sehat.jakarta:PT.Rineka Cipta.

Setiadi. 2007. Konsep dan Penulisan Riset Keperawatan. Yogyakarta: Graha Ilmu.

Tjokro prawiro, Askandar. 2003. Menuju Hidup Sehat mengkonsumsi air bersih yang sehat.Jakarta: Gramedia Pustaka.

Tjokro prawiro, Askandar. 2004. Hidup Sehat dan Bahagia keluarga mengkonsumsi air bersih yang sehat.Jakarta: Gramedia Pustaka.

Wakurnia Wati.2010.Analisa KualitasFisik, 
Bakteriologis Dan Kimia Air Sumur Gali Serta Gambaran Keadaan Konstruksi Sumur Gali.Jakarta:Berkat putra 